\title{
KEMAMPUAN BERFIKIR KRITIS SISWA MENGGUNAKAN PENDEKATAN PEMBELAJARAN REALISTIC MATHEMATIC EDUCATION (RME) PADA MATERI SPLDV
}

\author{
${ }^{1}$ Putri Suci Ramadani \\ ${ }^{1}$ (Program Studi Pendidikan Matematika FKIP Universitas Muhammadiyah Sukabumi) \\ 1 putriscr15@gmail.com
}

\begin{abstract}
ABSTRAK
Penelitian ini bertujuan untuk mendeskripsikan kemampuan berfikir kritis siswa dilihat dari bagaimana siswa menyelesaikan soal matematika pada materi Sistem Persamaan Linear Dua Variabel (SPLDV). Dalam soal uraian, siswa dapat menyelesaikan soal untuk mengetahui kemampuan berfikir kritis dengan pembelajaran menggunakan pendekatan RME. Pendekatan penelitian yang digunakan adalah pendekatan kualitatif dengan jenis penelitian studi kepustakaan. Dari hasil tersebut dapat disimpulkan bahwa pengguaan pendekatan pembelajran RME diharapkan dapat berpengaruh terhadap kemampuan berfikir kritis matematika, hal ini disebabkab karena dengan menggunakan kemampuan berfikir kritis, siswa mampu menyelesaikan soal cerita sistem persamaan linear dua variabel dengan adanya bimbingan dari guru yang dilaksankan melalui diskusi guru dengan siswa secara umum dalam menerapkan pendekatan pembelajaran Realistic Mathematics Education (RME).
\end{abstract}

Kata Kunci: Kemampuan Berfikir Kritis, RME, Materi SPLDV.

\section{PENDAHULUAN}

Pada saat ini, pendidikan dapat dikatakan sebagai suatu kebutuhan yang sangat penting. Pendidikanlah yang dapat menuntun serta menentukan arah hidup seseorang. Pendidikan dibutuhkan oleh semua orang karena dengan adanya pendidikan, manusia dapat mengembangkan kemampuan diri mereka sendiri dalam sikap dan perilaku bermasyarakat. Dengan semakin berkembangnya zaman, maka pendidikan menjadi hal yang sangat dibutuhkan oleh manusia di masa ini. Hal ini karena dengan pendidikan, maka manusia memiliki bekal untuk dapat mengikuti dan menghadapi setiap perubahan yang ada, misalkan perubahan akibat perkembangan ilmu pengetahuan dan teknologi. Hal tersebut jelas menunjukan bahwa betapa pentingnya pendidikan bagi manusia di zaman yang sudah sangat maju ini.

Matematika merupakan salah satu dari banyaknya ilmu pengetahuan, dimana matematika sendiri merupakan ilmu yang mendasari berbagai ilmu pengetahuan lain. Matematika dapat di kaitkan dengan berbagai ilmu pengetahuan. Matematika merupakan ilmu universal yang menjadi dasar perkembangan ilmu pengetahuan dan teknologi modern serta memajukan daya pikir dan analisa manusia. Manusia dituntut untuk dapat berfikir logik dan realistis untuk dapat memahami dan menguasai matematika. Matematika dapat diajarkan menggunakan berbagai macam pendekatan pembelajaran. Hal ini dapat disesuaikan dengan keadaan dan kebutuhan dalam proses pembelajaran. Pendekatan yang digunakan tidak harus sama pada setiap materi yang akan diajarkan karena setiap materi memiliki karakteristiknya masing-masing. Kegiatan yang dilakukan dalam proses pembelajaran matematika bertujuan agar kegiatan pembelajaran tersebut dapat bermakna sesuai pendekatan yang digunakan di masa ini yaitu mengamati, menanya, menalar, mencoba dan menyaji serta mencipta atau biasa disebut dengan pendekatan ilmiah. Dari tujuan pembelajaran matematika tersebut, dapat diketahui bahwa siswa dituntut untuk dapat berfikir secara logis, sistematis, analitis, kritis, dan kreatif dalam memecahkan suatu permasalahan matematika.

Di zaman yang sudah sangat maju ini, pola fikir kritis sangatlah penting untuk diaplikasikan dalam keseharian hidup kita. Menurut Elaine B. Johnson (2007), berpikir kritis adalah suatu proses yang terorganisasi dengan jelas yang dipakai dalam aktivitas mental seperti menyelesaikan permasalahan, membuat keputusan, membujuk, melakukan analisis terhadap suatu asumsi, serta melaksanakan kegiatan penelitian ilmiah. Pola fikir yang kritis dapat membantu manusia dalam pengambilan keputusan secara selektif. Sebagai siswa, menerapkan pola fikir kritis akan memberi manfaat di berbagai bidang. Keterampilan berfikir kritis merupakan bagian penting yang berpengaruh dalam kehidupan akademik siswa. Siswa harus dapat menerapkan dan mengembangkan pola fikir kritis dalam berbagai aspek, seperti ketika membaca, ketika menulis, dan ketika bekerja sama dengan siswa lain. Berfikir secara kritis adalah dengan memeriksa ide, mengevaluasi terhadap pengetahuan yang sudah dimiliki serta membuat keputusan yang rasional sesuai 
dengan fakta yang terdapat di lapangan. Ketika individu berfikir kritis, individu tersebut akan menimbang semua sisi argumen dan mengevaluasi kekuatan dan kelemahannya.

Sistem persamaan linear dua variabel adalah salah satu mata pelajaran yang diajarkan di satuan pendidikan tingkat menengah pertama kelas VIII semester satu. Sistem persamaan linear dua variabel merupakan mata pelajaran yang membutuhkan penalaran yang tinggi. Pada sistem persamaan linear siswa diminta untuk mampu mengubah permasalahan nyata kedalam model matematika. Dalam hal ini, siswa tidak hanya mengandalkan kemampuan mengingat (recall), akan tetapi juga kemampuan untuk menginterpretasikan soal dimana hal ini membutuhkan tingkat berfikir yang tinggi. Siswa diharuskan untuk dapat berfikir secara kritis, analitis, dan sistematis untuk dapat menyelesaikan soal persamaan linear dua variabel.

Salah satu faktor penyebab rendahnya kemampuan berfikir kritis adalah pendekatan pembelajaran. Dapat dilihat dari beberapa penelitian rendahnya kemampuan berfikir kritis siswa. Antara lain hasil penelitian Suryanto dan Somerset (Fachrurazi, 2011: 76) terhadap 16 Sekolah Lanjutan Pertama pada beberapa provinsi di Indonesia menunjukkan sangat rendah hasil tes mata pelajaran matematika, terutama pada soal cerita matematika. Penggunaan metode pembelajaran sangat penting dalam proses pembelajaran di dalam kelas. Pendekatan pembelajaran dapat diartikan sebagai sudut pandang terhadap proses pembelajaran, yang merujuk pada pandangan tentang terjadinya suatu proses yang sifatnya masih sangat umum, dan melatari metode pembelajaran dengan cakupan teoritis tertentu. Dilihat dari pendekatannya, pembelajaran terbagi 2 jenis pendekatannya, yaitu: (1) pendekatan pembelajaran yang berorientasi atau berpusat pada siswa (studentcentered approach) dan (2) pendekatan pembelajaran yang berorientasi atau berpusat pada guru (teachercentered approach). Menurut pendapat Wahjoedi (1999: 121) bahwa "Pendekatan pembelajaran adalah cara mengelola kegiatan belajar dan prilaku siswa agar ia dapat aktif melakukan tugas belajar sehingga dapat memperoleh hasil belajar secara optimal".

Dalam kaitan pentingnya permasalahan di atas, maka diterapkan pembelajaran matematika yang menggunakan pendekatan pembelajaran Realistic Mathematics Education yang bertujuan untuk meningkatkan kemampuan berfikir kritis matematis siswa. Tujuan dari penelitian ini adalah untuk mengetahui bagaimana efektifitas penerapan model pembelajran Realistic Mathematics Education terhadap kemampuan berfikir kritis matematis siswa.

\section{Berfikir Kritis Matematika}

Cara berfikir manusia dibagi kedalam beberapa kelompok, yaitu: berfikir vertikal, lateral, kritis, analitis, strategis, berfikir tentang hasil, dan berfikir kreatif (DePoter dan Hemacki, 1991: 296). Menurut keduanya, berfikir kritis merupakan melatih atau memasukkan penilaian atau juga evaluasi yang cermat, seperti saat menilai kelayakan suatu gagasan ataupun produk. Dalam berfikir kritis juga memiliki tujuan, yaitu untuk memberi keputusan mengenai sesuatu atau prtimbangan.

Keterampilan kognitif berfikir kritis dibagi kedalam 5 bagian. yaitu: (1) Klarifikasi elementer (Elementary Clarification), (2) dukungan dasar (Basic Support), (3) penarikan kesimpulan (Inference), (4) klarifikasi lanjut (Advanced Clarification), (5) strategi dan taktik (Strategies dan Tactics) menurut Ennis (1985: 43). Berfikir kritis adalah menjelaskan apa yang difikirkan. Belajar untuk berfikir kritis berarti belajar: apa pertanyaannya, bagaimana bertanya, bagaimana nalarnya, kapan menggunakan penalaran, serta yang digunakannya metode penalaran apa. Apabila siswa tersebut mampu menguji pengalamannya, mengevaluasi pengetahuan, ide-ide, dan mempertimbangkan argumen sebelum mendapatkan justifikasi, maka dapat dikatakan siswa tersebut berfikir kritis. Harus dikembangkan sikap-sikap keinginan untuk bernalar, ditantang, dan mencari kebenaran agar siswa menjadi pemikir kritis menurut Fisher (dalam Ismaimuza, 2010).

Perlu adanya tahapan atau fase-fase yang harus dikembangkan siswa selama proses pembelajaran berlangsung untuk mengembangkan kemampuan berfikir kritis. Noer (2010) merangkum beberapa pendapat dari para ahli mengenai fase-fase berfikir kritis dan berfikir kritis dibagi menjadi 4 fase yaitu:

1. Kepekaan: merupakan memahami suatu isu, proses memicu masalah, kejadian, dilema dari berbagai sumber (tanggap terhadap masalah). istilah trigger event atau klarifikasi, istilah tersebut biasanya digunakan dalam hal ini.

2. Kepedulian: merupakan proses merencanakan solusi suatu isu, masalah, dilema dari berbagai sumber. Istilah appraisal, klarifikasi dasar, assesing evidence, dan eksplorasi beberapa istilah tersebut digunakan oleh beberapa para ahli.

3. Produktivitas: merupakan tugas mengkonstruksi gagasan untuk menyelesaikan masalah, menyimpulkan dan menilai kesimpulan. Eksplorasi dan menarik kesimpulan, para ahli menggunakan istilah tersebut.

4. Reflektif: merupakan proses memeriksa kembali solusi yang telah dikerjakan dan mengembangkan 
strategi alternatif. Alternatif perspektif, klarifikasi tingkat tinggi, integrase, strategi, cara-cara, dan resolusi, istilah tersebut digunakan oleh para ahli.

Guru hendaknya memfasilitasi dan melakukan tindakan yang mendorong siswa mereflesikan kemampuannya dalam mengembangkan kemampuan berfikir kritis. Adapun untuk kepentingan penelitian ini indikator kemampuan berfikir kritis matematis siswa dibatasi, dilihat dari aspek mengidentifikasi, menghubungkan, mengevaluasi dan menganalisis.

\section{METODE PENELITIAN}

Metode penelitian yang digunakan dalam penelitian ini adalah metode kualitatif dengan jenis penelitian kepustakaan. Penelitian kepustakaan merupakan penelitian yang pada umumnya dilaksanakan dengan cara tidak turun ke lapangan dalam pencarian datanya, penelitian kepustakaan ini jenis penelitian kualitatif. Adapun menurut Noeng Muhadjir (1996: 169) penelitian kepustakaan yaitu penelitian yang lebih memerlukan olahan filosofis dan teoritis dari pada uji empiris dilapangan. Karena sifatnya yang teoritis dan filosofis, penelitian kepustakaan lebih sering menggunakan pendekatan filosofis (philosophical approach) dibandingkan pendekatan yang lain. Metode penelitian kepustakaan mencakup sumber data, pengumpulan data, dan analitis data.

\section{HASIL DAN PEMBAHASAN}

Pendidikan matematika realistis atau Realistic Mathematics Education (RME) adalah suatu pendekatan belajar matematika yang memberikan pengalaman langsung dengan pengalaman mereka sendiri dan juga menempatkan permasalahn matematika dalam kehidupan sehari-hari sehingga mempermudah siswa menerima materi. Adapun menurut Aisyah (2007), Realistic Mathematics Educations (RME) merupakan suatu pendekatan belajar matematika yang dikembangkan untuk mendekatkan matematika kepada siswa. Masalah-masalah nyata dari kehidupan seharihari yang dimunculkan sebagai titik awal pembelajaran matematika. Selain itu menurut Asih dan Edy (2017) pendekatan Realistic Mathematics Education pada materi pembagian pecahan telah berhasil meningkatkan kemampuan berfikir kritis siswa. Hal ini terlihat dari indikator siswa dalam mengidenfikasi, mengklarifikasi, menganalisis, mengevaluasi, dan menyimpulkan ratarata telah mencapai kategori kritis. Menurut Nina Munazilla (2019) kemampuan berfikir kritis siswa dalam menyelesaikan soal persamaan linear dua variabel (SPLDV) menunjukkan bahwa siswa sudah sangat mampu dalam menjelaskan informasi-informasi pokok yang terdapat dalam soal. Siswa sudah memberikan argumen yang benar dan disertai dengan alasan yang tepat. Siswa belum bisa menyelesaikan permasalahan dengan menggunakan beragam alternatif penyelesaian, dan siswa juga sudah bisa menyimpulkan hasil penyelidikannya dengan logis dan jelas.

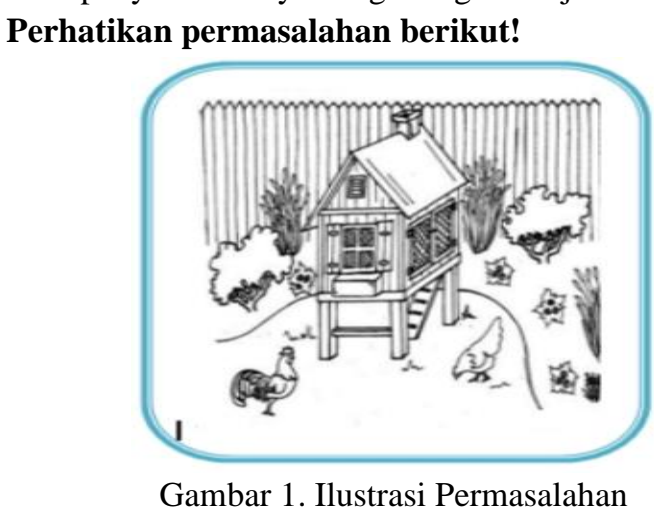

Pak Hendra memelihara ayam dan kambing. Ketika temannya menanyakan jumlah ternaknya, Pak Hendra menjawab bahwa jumlah kepala ternaknya 14 dan jumlah kakinya adalah 36. Dapatkah kalian tentukan banyaknya ayam dan kambing milik Pak Hendra?

1. Pak Hendra memelihara ayam dan kambing, jumlah kepala ternak Pak Hendra adalah 14.

a. Mungkinkah ayam Pak Hendra ada 10 ekor? Jelaskan!

b. Jika banyaknya kambing Pak Hendra adalah 6 ekor. Berapakah banyaknya ayam Pak Hendra?

c. Tentukan beberapa kemungkinan banyaknya ayam Pak Hendra?

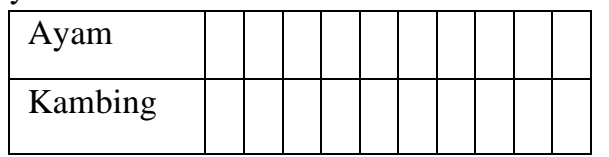

Dari gambar 1 di atas dapat dilihat bahwa dalam Realistic Mathematics Education dengan materi sistem persamaan linear dua variabel, siswa dikenalkan soal cerita dalam kehidupan sehari-hari.

Pendekatan pembelajaran ini mengacu pada pendapat Freudental yang menyatakan bahwa matematika adalah aktivitas manusia. Pendekatan Belanda ini dikenal nama Realistic Mathematics Education. Treffers (I Gusti Ayu Arista Widari, I Gusti Ngurah Nila Putra, I Ketut Suwija, 2013) menyebutkan bahwa karakteristik dari pembelajaran matematika 
yaitu: (1) Selfdeveloped models penggunaan model, istilah model berkaitan dengan situasi dan model matematika yang dikembangkan sendiri oleh siswa. Peran selfdeveloped models adalah jembatan bagi siswa dari konteks informal ke formal dimana siswa membuat model sendiri dalam menyelesaikan masalah sehingga diperoleh pengetahuan matematika formal (bersifat abstrak) atau juga dari situasi konkret menuju abstrak, (2) menggunakan dunia nyata, pembelajaran diawali dengan masalah konstektual (dunia nyata) sehingga memungkinkan siswa menggunakan pengalaman sebelumnya secara langsung untuk menemukan suatu konsep. Melalui abstraksi dan formalisasi, siswa dapat mengembangkan konsep yang lebih komplit. Kemudian siswa dapat mengaplikasikan konsep-konsep matematika kedalam bidang yang lain ataupun dunia nyata sehingga memperkuat pemahaman konsep, (3) menggunakan produksi dan konstruksi oleh siswa, siswa mempunyai kesempatan untuk mengembangkan strategi-strategi informal pemecahan masalah yang dapat mengarah pada konstruksi prosedur-prosedur pemecahan masalah. Dengan bimbingan guru, siswa diharapkan menemukan kembali konsep dalam bentuk formal, (4) intertwinement atau keterakitan unit belajar, dalam pembelajaran matematika realistik, keterkaitan unit-unit matematika adalah esensial. Dengan keterkaitan ini akan memudahkan siswa dalam berfikir kritis, (5) menggunakan interaktif, interaksi antara siswa dan guru merupakan hal mendasar dalam pembelajaran matematik realistic. Secara eksplisit bentuk-bentuk interaksi yang berupa negoisasi, penjelasan, pembenaran, setuju, tidak setuju, pernyataan atau refleksi digunakan untuk mencapai bentuk formal dari bentuk-bentuk informal siswa.

Kemampuan berfikir kritis sangat perlu dikembangkan dalam pembelajaran matematika karena dengan berfikir kritis siswa dapat menganalisis pemikirannya untuk menarik kesimpulan dan untuk memutuskan suatu pilihan. Indikator strategi dan teknik dapat dipenuhi apabila siswa dapat mengeksplor kemampuannya dengan berfikir secara kreatif. Untuk mendukung hasil tersebut, maka sangat penting untuk memilih pendekatan pembelajaran yang tepat sehingga keterampilan siswa dalam berfsikir kritis dapat direalisasikan. Untuk dapat meningkatkan kemampuan berfikir kritis dibutuhkan suatu pendekatan pembelajaran yang tepat dan dapat meningkatkan kualitas dan minat siswa. Hal tersebut dapat dicapai dengan penerapan pendekatan Realistic Mathematics Education, merupakan suatu pendekatan dalam pembelajaran matematika yang berdasarkan pernyataan Freudenthal bahwa matematika merupakan suatu bentuk aktivitas manusia. Hal ini sesuai dengan hasil penelitian dari Dian Kusuma Wardani (2018) yang mengatakan bahwa dengan menerapakan model pembelajaran Realistic Mathematics Edication (RME) dalam suatu proses pembelajaran dapat meningkatkan minat dan kualitas siswa yang pada akhirnya berakibat pada peningkatan kemampuan berfikir kritis dan analitis siswa.

Memiliki pola fikir yang kritis akan sangat membantu seseorang dalam segala bidang di kehidupannya. Kemampuan ini tidaklah datang dengan sendirinya, melainkan melalui pengasahan kemampuan yang dilakukan secara terstruktur. Salah satu tempat yang dapat membantu untuk mengembangkan kemampuan berfikir kritis adalah sekolah. Sekolah merupakan tempat berlangsungnya kegiatan belajar mengajar antara guru dan siswa, dimana siswa akan dibimbing dan diarahkan melalui proses pembelajaran. Disamping siswa yang menjadi subjek dalam proses pembelajaran, guru juga memiliki andil besar dalam tercapainya proses pembelajaran yang maksimal. Pada penelitian ini, diketahui bahwa siswa masih diberikan petunjuk dan arahan oleh guru sebelum melakukan pengerjaan soal kemampuan berfikir kritis. Walaupun siswa sudah mendapatkan kisi-kisi tes yang akan diujikan sebelumnya, akan tetapi guru mata pelajaran yang bersangkutan masih memberikan petunjuk serta arahan-arahan dalam pengerjaan soal tes. Hal ini sesuai dengan hasil penelitian dari Agoestanto, A. dan Sukestiyarno, Y.L. (2017) yang mengatakan bahwa kemampuan berfikir kritis matematis siswa SMP masih menjadi tanggung jawab guru, guru perlu memfasilitasi siswa dalam belajar untuk mengembangkan pemikiran kritis.

Dengan menggunakan kemampuan berfikir kritis, siswa mampu menyelesaikan soal cerita sistem persamaan linear dua variabel dengan adanya bimbingan dari guru yang dilaksankan melalui diskusi guru dengan sisiwa secara umum dalam menerapkan pendekatan pembelajaran Realistic Mathematics Education (RME). Dalam penelitian ini siswa sendiri yang menemukan model matematika dari soal cerita (Fristita Desania dan Edy Surya, 2018).

\section{KESIMPULAN}

Berdasarkan hasil penelitian tersebut maka dapat disimpulkan bahwa penerapan pendekatan pembelajaran Realistic Mathematics Education (RME) diharapkan dapat meningkatkan kemampuan berfikir kritis matematis siswa, hal ini disebabkan karena Dengan menggunakan kemampuan berfikir kritis, siswa mampu menyelesaikan soal cerita sistem persamaan linear dua variabel dengan adanya bimbingan dari guru yang dilaksankan melalui diskusi guru dengan siswa 
secara umum dalam menerapkan pendekatan pembelajaran Realistic Mathematics Education (RME). Profil proses berfikir kritis siswa dalam menyelesaikan soal persamaan linear dua variabel adalah siswa mampu mengidentifikasi dan menjelaskan semua informasi pokok dari permasalahan yang terdapat dalam semua soal. Siswa mampu dalam mengambil keputusan dengan memberikan argumen yang benar dan disertai dengan alasan yang tepat yang berguna untuk mendukung argumennya tersebut pada semua soal. Siswa sudah mampu dalam membentuk kesimpulan terhadap hasil penyelidikannya dengan jelas dan logis untuk semua soal.

\section{DAFTAR PUSTAKA}

Agoestanto, A. dan Sukestiyarno, Y.L., 2017. “Analysis of Mathematics Critical Thinking Students in Junior High School Based on Cognitive Style." Journal of Physics 824(1): 1742-6596.

Fisher, A. 2009. Berpikir Kritis: Sebuah Pengantar. Jakarta: Erlangga.

Johnson, E. B. 2007. Contextual Teaching and Learning: Menjadikan Kegiatan BelajarMengajar Mengasyikkan dan Bermakna. Bandung: Mizan Learning Center (MLC).

Munazill, N. 2019. "Kemampuan Berpikir Kritis Siswa Kelas VIII dalam menyelesaikan soal Sistem Persamaan Linear Dua Variabel". FKIP. Universitas Muhammadiyah Surakarta. Surakarta.

Noordyana, M. S. 2016. "Meningkatkan Kemampuan Berpikir Kritis Matematis Siswa melalui Pendekaatan Metacognitive Instruction". Jurnal Mosharafa, Volume 5 Nomor 2. 2 Mei 2016.

Kusuma, D. W. 2016. "Profil Kemampuan Berfikir Kritis Siswa Menggunakan Model Pembelajaran Realistic Mathematics Education (RME) Pada Materi Sistem Persamaan Linear Dua Variabel (SPLDV) Siswa kelas VIII SMPN 1 Mojo Kediri”. FKIP. Universitas Nusantara PGRI Kediri. Kediri. 